\title{
Extracardiac Rhabdomyoma Mimicking Plunging Ranula
}

\section{Servikal Ranulayı Taklit Eden Ekstrakardiyak Rabdomiyom}

\author{
Ikram HAKIM $\odot$, Mohd Razif Mohamad YUNUS $\odot$
}

Ethics Committee Approval: Not Applicable.

Conflict of interest: The authors declare that they have no conflict of interest.

Funding: None.

Informed Consent: Informed consent was taken.
Cite as: Hakim I, Yunus MRM. Extracardiac rhabdomyoma mimicking plunging ranula. Medeni Med J. 2020;35:271-5.

\begin{abstract}
Histopathologically adult extracardiac rhabdomyoma is a benign tumour of mature striated muscle. It is a slow- growing tumour with predilection to occur in head and neck region. They appear mainly as a solitary lesion, and about $15 \%$ of them can be multicentric. A 56-year-old man presented to us with the floor of mouth swelling persisted for one year and the right neck swelling for three years mimicking a plunging ranula. Radiological imaging revealed enhancing mass at the floor of mouth and submandibular region. The mass represented a nonvascular benign tumour. Subsequently, the patient underwent excision of the mass via transcervical and transoral method. Histopathological examination revealed adult type of extracardiac rhabdomyoma. Adult type of extracardiac rhabdomyoma should be considered in the differential diagnosis for the head and neck masses. A complete excision will reduce the risk of recurrence.
\end{abstract}

Keywords: Adult rhabdomyoma, plunging ranula, neck swelling, neck malignancy, extracardiac rhabdomyoma

öz

Erişkin tipte ekstrakardiyak rabdomiyom, olgunlaşmış çizgili kasta ortaya çıkan histopatolojik açıdan iyi huylu bir tümördür. Baş ve boyun bölgesinde daha fazla belirmekte ve yavaş yavaş büyümektedir. Esas olarak soliter olmakla beraber, \%15 civarında multisentrik olabilen bir lezyon gibi görünmektedir. Bize 56 yaşında bir erkek hasta, servikal ranulayı taklit eden ve bir yıl boyunca ağız tabanında şişlik ve üç yıl boyunca sağ boyunda șişlik tablosuyla gelmiştir. Radyolojik görüntüleme ağız ve submandibular bölgede kitlenin arttığını göstermiştir. Kitle vasküler olmayan iyi huylu bir tümörü temsil etmiştir. Daha sonra, hastaya kombine transservikal ve transoral yöntemler ile eksizyon yapılmıştır. Histopatolojik incelemede erişkin tipte ekstrakardiyak rabomiyom saptanmıştır. Baş ve boyun kitlelerinde ayırıcı tanı olarak erişkin tipte ekstrakardiyak rabdomiyom düşünülmelidir. Tam bir eksizyon nüks riskini azaltacaktır.

Anahtar kelimeler: Erişkin rabdomiyom, servikal ranula, boyun şişmesi, boyun malignitesi, ekstrakardiyak rabdomiyom
Received: 18 May 2020

Accepted: 19 July 2020

Online First: 30 September 2020

Corresponding Author:

M.R.M. Yunus

ORCID: 0000-0002-8563-9000

Universiti Kebangsaan

Malaysia Medical Center,

Department of Otorhinolaryngology

and Head and Neck Surgery,

Kuala Lumpur, Malaysia

razif72@gmail.com

\section{Hakim}

ORCID: 0000-0003-4589-9665 Universiti Kebangsaan Malaysia Medical Center, Department of Otorhinolaryngology and Head and Neck Surgery,

Kuala Lumpur, Malaysia 


\section{INTRODUCTION}

Rhabdomyoma is an unusually slow-growing benign tumor and histopathologically they arise from mature striated muscle. Rhabdomyoma can be classified as cardiac rhabdomyoma and extracardiac rhabdomyoma. As the name suggests, cardiac rhabdomyoma occurs mainly in the heart of the infant while extracardiac rhabdomyoma occurs elsewhere ${ }^{1}$. Extracardiac rhabdomyoma consists of adult, fetal, and genital types. Adult type is being the most common type among them. It is commonly found in middle-aged males and reported to have a favorable site of occurrence in the head and neck region ${ }^{1,2}$. It appears mainly to be a solitary lesion, and $15 \%$ of them can be multicentric ${ }^{2}$. In this case report, we share our experience in managing a case of multifocal extracardiac rhabdomyoma which mimicked plunging ranula in its presentation. To the best of our knowledge, multifocal extracardiac rhabdomyoma of the head and neck region is a rare presentation, and only in sparse cases, this lesion involved both the floor of the mouth and submental space.

\section{CASE HISTORY}

A 56-year-old man presented to us with right neck swelling persisting for three years. The swelling was painless and had grown slowly over the years. He developed a new swelling over the floor of mouth two years later which made him seek medical attention. Otherwise, he did not have any compressive symptoms such as stridor, hoarseness, shortness of breath, dysphagia or odynophagia. On examination, there was submental and submandibular swelling both with a well-defined contour, and measuring about $4 \mathrm{~cm} \times 2 \mathrm{~cm}$ without any cutaneous changes The mass was non-tender with soft consistency. The right side of floor of the mouth was raised with firm consistency. Movement of the tongue was normal any deviation or fasciculation was not seen. Flexible nasopharyngolaryngoscope showed raised right-sided base of the tongue with normal supraglottic and laryn- geal structures. Bilateral vocal cords were mobile. Computed tomography of the neck revealed heterogeneous enhancing mass at the floor of mouth measuring $7.2 \mathrm{~cm} \times 4.6 \mathrm{~cm} \times 2.9 \mathrm{~cm}$ with the presence of small patchy area which might represent vascular pool channels. Prominent feeding vessel supply as the lingual artery could be seen. Another mass was located in the submandibular region with a similar appearance (Figure 1) which did not contain any calcification or fluid. Later, he underwent magnetic resonance Imaging (MRI). MRI of the neck showed ill-defined mass which was isointense to the muscle on T1 WI and hyperintense on T2WI, involving most of the right hemi tongue and the floor of the mouth. The mass measured approximately $7.1 \mathrm{~cm} \times 3.5 \mathrm{~cm} \times 5.5 \mathrm{~cm}$ (Figure 2). Inferiorly involvement of the right genioglossus, hyoglossus, and mylohyoid muscles with extension into the posterior part of the sublingual space was obvserved. The rest of the extrinsic muscles of the tongue were preserved while submandibular glands and parotid glands were normal. Magnetic resonance angiogram (MRA) did not reveal any arterial feeder from the lingual artery. We performed a combined approach namely excision of right submandibular space tumor and transoral resection of the mass on the floor of mouth. Intraoperatively, soft fleshy mass at the submandibular space measured $4.5 \mathrm{~cm} \times 3 \mathrm{~cm}$ (Figure 3). The mass pushed the anterior belly of digastric muscle superiorly, and lied just inferior to the mylohyoid muscle. Mylohyoid muscle was intact without any evidence of tumoral invasion. The right submandibular gland was intact. There was also a multilobulated soft fleshy mass located at the right side of the floor of the mouth (Figure 4). The mass was easily separated with blunt dissection and removed in pieces. Inferiorly, the mylohyoid muscle was intact with no evidence of tumor penetration. Macroscopically, both tumors had a similar appearance, and were fleshy, soft with a smooth surface, and multilobulated. Histopathology revealed an adult type of extracardiac rhabdomyoma. To this date, the patient has been well with no evidence of recurrence after a year on follow-up. 

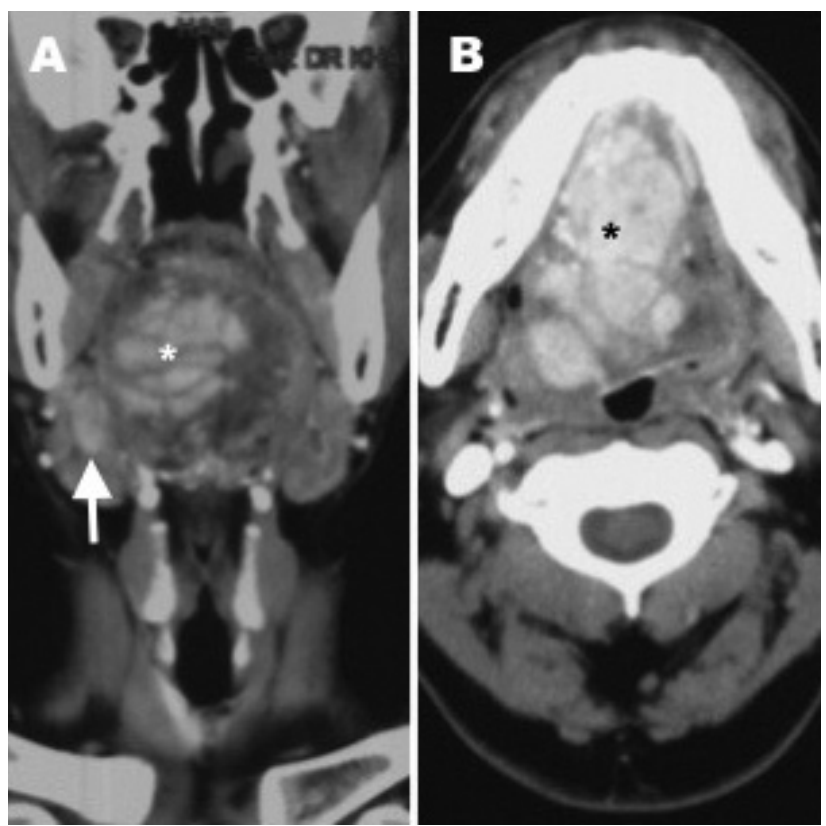

Figure 1. CT scan shows coronal (A) and axial (B) cut. There are enhancing mass at floor of mouth $\left({ }^{*}\right)$ and submandibular mass (arrow).
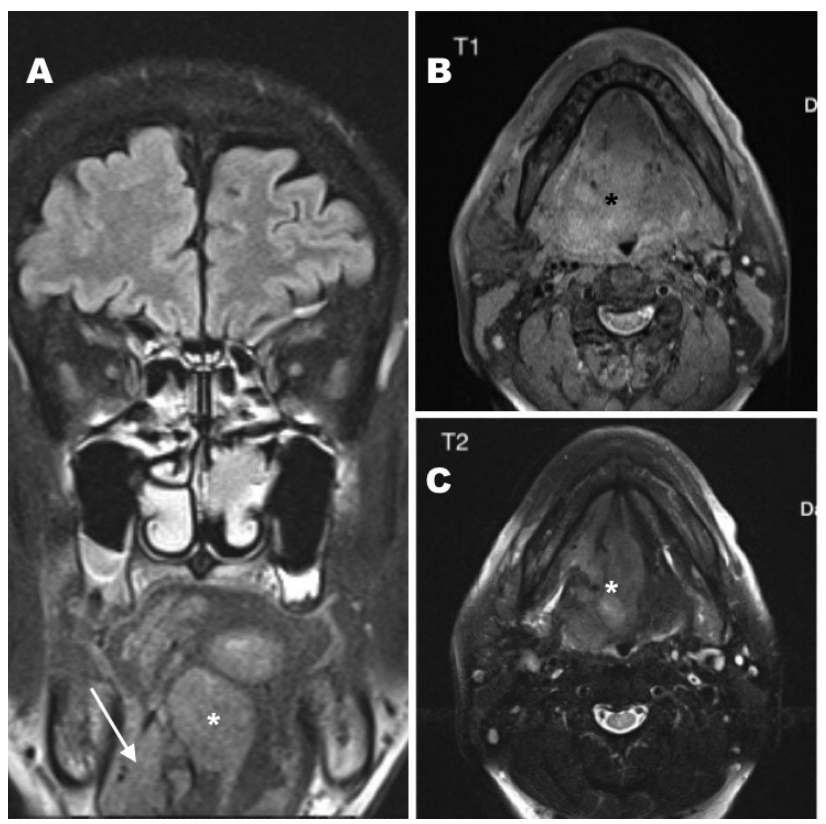

Figure 2. (A) Coronal cut shows floor of mouth mass (*) and Submandibular mass (arrow). (B) T1 weighted axial cut shows isotense lesion at floor of mouth. (C) T2 weighted axial cut shows hyperintense lesion at floor of mouth.

\section{DISCUSSION}

Adult type of extracardiac rhabdomyoma is a rare benign tumor with mature skeletal muscle

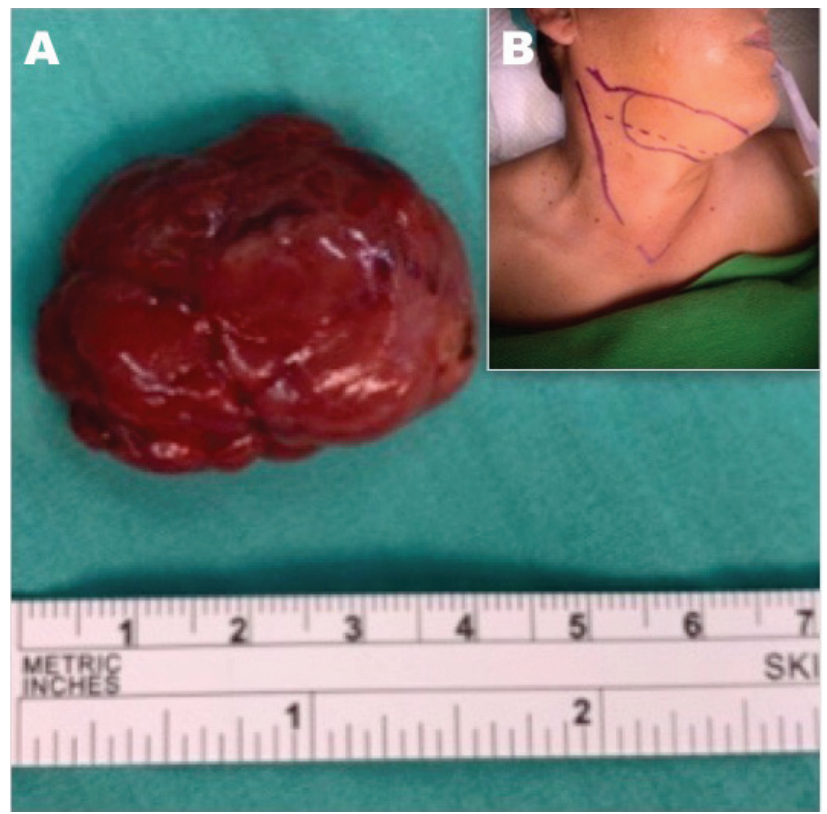

Figure 3. (A) Rhabdomyoma of submandibular region. (B) Transcervical approached for excision of submandibular mass and submental.
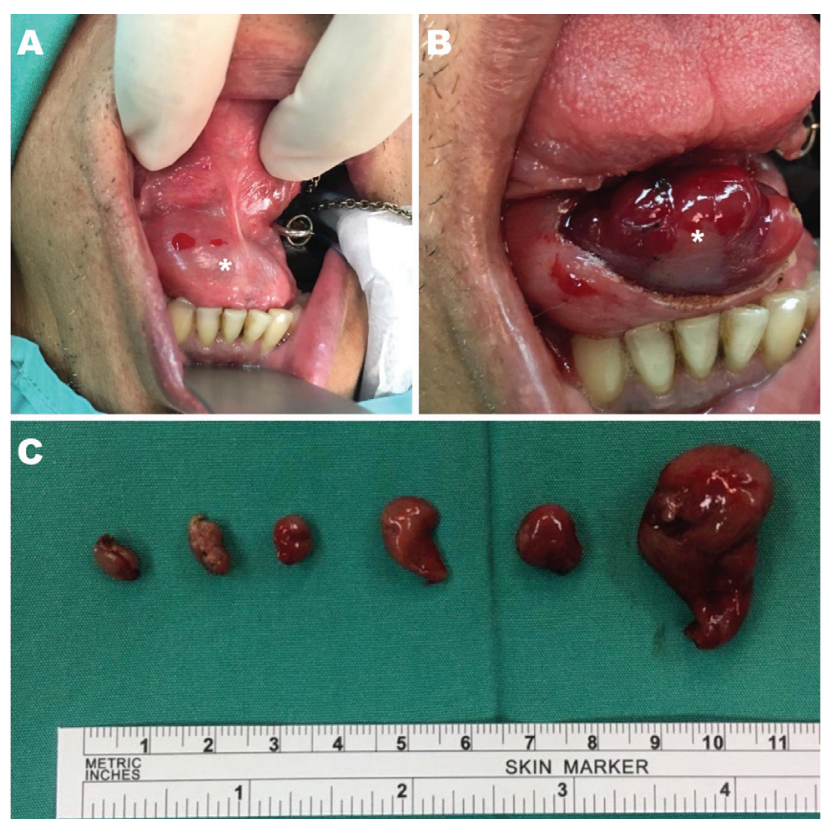

Figure 4. (A) Raised floor of mouth on the right side $\left(^{*}\right)$. (B) Appearance of rhabdomyoma after incision at floor of mouth (*). (C) Multilobulated mass separated after excision of rhabdomyoma.

tissue. Nighty percent of the cases this tumor is mainly found in the head and neck region ${ }^{3}$. The predilection of this tumor for the head and neck region is a fact, because the tumor arises from 
the musculature of the third and fourth branchial arches. This tumor favors male gender aged between 55 to $60^{1}$. Usually, the tumor appears as a painless slow-growing mass. However, some authors have suggested that the symptoms of rhabdomyoma depend on the site of the tumor itself. Parapharyngeal rhabdomyoma may present with compressive symptoms such as globus sensation, hoarseness or dysphagia. The tumor can occur in various sites of the head and neck region such as oral cavity, submandibular region, tongue, pharynx, larynx, soft palate, thyroid, cheek, tonsillar region, and parapharyngeal space. It can also manifests itself as solitary, even multinodular or multifocal lesions ${ }^{4}$.

In our case, the patient presented with submandibular and submental swelling with extension to the floor of the mouth. At a glance, the patient looked like to have a plunging ranula as the neck swelling was soft in consistency like a cystic lesion. However, the submental swelling was firm which resulted in a diagnostic dilemma. Probable differential diagnosis could be a neurogenic or vascular tumor, oncocytoma, granular cell tumor, and rhabdomyosarcoma ${ }^{5}$. Hence, according to the clinical findings, we proceeded with radiological imaging to assist us in making the diagnosis. Fine needle aspiration was possible to perform on the submental region but the floor of mouth lesion withheld us to proceed with the procedure, because a vascular tumor was also considered in differential diagnosis. Thus, imaging could help us differentiate between tumor situated in both locations.

In our experience, extracardiac rhabdomyoma in the head and neck region is rare, hence the appearance in CT scan and MRI has not been very well delineated. These imaging modalities are helpful to determine the characteristics, the extent of the tumor, and the probability of multifocality of the mass.

The computed tomography of the neck showed enhancing mass at the floor of mouth with the presence of a patchy area of enhancement that might represent vascular pool channels. Liang et al. $^{6}$ stated that adult rhabdomyoma might mimic a malignant tumor in CT scan due to indistinct borders between the mass and adjacent isodense muscle. However, our CT scan showed enhancing mass which most likely to be a vascular mass. Thus, we started to obtain an MRI the head and neck region and relevant MRA to evaluate the mass on the floor of mouth in greater detail. Generally, rhabdomyoma presents as a homogenous lesion with isointense or hyperintense to muscle in T1- and T2- weighted images. In adult rhabdomyoma MRI allows for a better soft tissue evaluation as it can display benign appearance with the absence of surrounding soft tissue invasion. Although radiological imaging alone will not differentiate rhabdomyoma from other benign lesions, absence of local invasion to surrounding tissues and muscles will help us to distinguish them from any malignant lesions. Helmberger et al. ${ }^{7}$ postulated that if the lesion involved the parapharyngeal space, it may be mistaken for a malignant neoplasm of minor salivary gland tumor. MRI and MRA made us to conclude that the mass extended to the sublingual space with the appearance of the benign lesion without an obvious feeding vessel. A thorough discussion in the radiology conference helped us in making a further final decision.

De Trey et al. ${ }^{8}$ described the macroscopic appearance of rhabdomyoma as soft, coarsely lobulated, tan-grey, well-circumscribed or encapsulated lesion which was correlated with operative findings of our case. Histopathological examination is the gold standard to confirm the diagnosis. Immunohistochemical stains are necessary to differentiate the skeletal muscle from other variety of tumors especially granular cell tumors, oncocytoma, hibernoma, and paraganglioma ${ }^{1}$.

The treatment of choice for rhabdomyoma is surgery. Many authors recommended complete ex- 
cision of the tumor as it is well circumscribed and easily removable with blunt dissection ${ }^{8}$. In our case, we used a combined approach of a transcervical and transoral method as the tumor occurred in two different locations. This finding was supported by evidence of the intact mylohyoid muscle without evidence of tumor invasion or penetration. Hence, it is best to do an excision with two different approaches to achieve complete excision similar to the management of plunging ranula. In excision of a plunging ranula combined approach (transoral and transcervical) has been favored by $49 \%$ of the surgeons, while transoral and transcervical approaches have been favored by $27 \%$, and $23 \%$ of the surgeons, respectively 9 .

Unfortunately, the recurrence rate of rhabdomyoma following excision has been reported to range between 16 and 42 percent $^{10}$. Multilobulation of the mass contributes to these high recurrence rates. The tumor remained unnoticed during complete removal as it may be attached to the main lesion by small strands of surrounding tissue ${ }^{8}$. A recurrent mass may develop decades later as the tumor is painless and slow growing in nature. Fortunately, no incidences of malignant transformation were reported in our case.

\section{CONCLUSION}

Adult type extracardiac rhabdomyoma is a rare benign tumor and most commonly found in the head and neck region. It should be considered for the differential diagnosis in the head and neck masses. Although the radiological examination fails to differentiate rhabdomyoma from other benign tumors, imaging is important to differentiate between malignant and benign neoplasms. In this case, the complete surgical excision with a combined approach as in the case with removal of plunging ranula is necessary to prevent any possible recurrence of rhabdomyoma.

\section{REFERENCES}

1. Weiss SW, Goldblum JR. Enzinger and Weiss's soft tissue tumors. Philadelphia, PA, Elsevier Health Sciences, 2007.

2. Liess BD, Zitsch RP 3rd, Lane R, Bickel JT. Multifocal adult rhabdomyoma: a case report and literature review. Am J Otolaryngol. 2005;26:214-7. [CrossRef]

3. Di Sant' Agnese PA, Knowles DM 2nd. Extracardiac rhabdomyoma: a clinicopathologic study and review of the literature. Cancer. 1980;46:780-9. [CrossRef]

4. Bellis D, Torre V, Nunziata R, et al. Submandibular rhabdomyoma: a case report. Acta Cytol. 2006;50:557-9. [CrossRef]

5. Metheetrairut C, Brown DH, Cullen JB, Dardick I. Pharyngeal rhabdomyoma: a clinico-pathological study. J Otolaryngol. 1992;21:257-61.

6. Liang GS, Loevner LA, Kumar P. Laryngeal rhabdomyoma involving the paraglottic space. AJR Am J Roentgenol. 2000; 174:1285-7. [CrossRef]

7. Helmberger RC, Stringer SP, Mancuso AA. Rhabdomyoma of the pharyngeal musculature extending into the prestyloid parapharyngeal space. AJNR Am J Neuroradiol. 1996;17:1115-8.

8. de Trey LA, Schmid S, Huber GF. Multifocal adult rhabdomyoma of the head and neck manifestation in 7 locations and review of the literature. Case Rep Otolaryngol. 2013;2013:758416. [CrossRef]

9. Samant S, Morton RP, Ahmad Z. Surgery for plunging ranula: the lesson not yet learned?. Eur Arch Otorhinolaryngol. 2011;268:1513-8. [CrossRef]

10. Kapadia SB, Meis JM, Frisman DM, Ellis GL, Heffner DK, Hyams VJ. Adult rhabdomyoma of the head and neck: a clinicopathologic and immunophenotypic study. Hum Pathol. 1993;24:608-7. [CrossRef] 